Article

\title{
Effects of Foliar Application of Urea and Urea-Formaldehyde/Triazone on Soybean and Corn Crops
}

\author{
Bruno Maia Abdo Rahmen Cassim ${ }^{1}$ (D, Antonio Pedro Martins Machado ${ }^{2}$, Daniel Fortune ${ }^{3}$, \\ Fernando Rodrigues Moreira ${ }^{2} \mathbb{D}$, Éder Júnior De Oliveira Zampar ${ }^{1}$ and \\ Marcelo Augusto Batista 1,*(D) \\ 1 Agronomy Department, Maringá State University (UEM), Maringá-PR 87020-900, Brazil; \\ bruno_cassim@hotmail.com (B.M.A.R.C.); eder_zampar@hotmail.com (É.J.D.O.Z.) \\ 2 Hexion Inc., Curitiba, Paraná 81460-050, Brazil; machado_antonio@hotmail.com (A.P.M.M.); \\ fernando.moreira@hexion.com (F.R.M.) \\ 3 Hexion Inc., Stafford, TX 77477, USA; daniel.fortune@hexion.com \\ * Correspondence: mabatista@uem.br; Tel.: +55-44-98415-6081
}

Received: 20 September 2020; Accepted: 8 October 2020; Published: 11 October 2020

\begin{abstract}
The objective of the study was to evaluate the effect of foliar application of urea and urea-formaldehyde, triazone-based fertilizers on soybean and corn crops. Four experiments were carried out, two on soybeans, one on first season corn, and the other on second season corn. The experiments were conducted using a randomized block design, with 5 treatments studied: T1 - control without application of foliar nitrogen $(\mathrm{N})$; T2-foliar application of conventional urea solution and three treatments with Hexion foliar fertilizers based on urea-formaldehyde and triazone (N-Hexion $\left.{ }^{\circledR}\right)$, with varying levels of $\mathrm{N}$ and slow-release components; T3-Hexion 1; T4-Hexion 2; and T5-Hexion 3. The foliar application of conventional urea showed no statistically significant difference in relation to the control for the yield components and grain yield for the soybean crops in seasons 2018-2019 and 2019-2020. Urea-formaldehyde/triazone treatments showed a significant increase in yield for soybeans in the 2018-2019 season compared to the control and to conventional urea. Nitrogen fertilizers with high percentages of slow-release compounds promote nitrogen release more slowly, which led to no significant increase in yield for Hexion 1. No statistical differences were observed in the corn yield for the first and second crop.
\end{abstract}

Keywords: nitrogen assimilation; slow-release fertilizer; foliar fertilization; complement of nitrogen fertilization; liquid fertilizers

\section{Introduction}

Soybean (Glycine max (L.) Merrill) and corn (Zea mays L.) are among the most economically important crops in Brazil. According to the United States Department of Agriculture, Brazilian soybean and corn production in the 2020-2021 harvest season will have a projected output of 131 and 106 million tons, respectively [1]. Crop yield is related to genotype, environment, and management. To maximize crop potential, the availability of nutrients must be synchronized with plant requirements [2].

In the case of nitrogen $(\mathrm{N})$, much of what is required by soybean in Brazil comes from a symbiotic relationship with Bradyrhizobium elkani and B. japonicum, which are provided by inoculation before or during sowing [3]. The bacteria infect the roots of the plant causing production of nodules at phenological stage V1. Throughout the vegetative stages of development, the number of nodules increases along with the rate of $\mathrm{N}_{2}$ fixation, reaching a peak at the grain filling stage, R5, and then decreasing rapidly thereafter [2]. 
The launch of cultivars with a high yield potential combined with research results on the response of soybean to the late application of $\mathrm{N}$ has raised doubts about the need for nitrogen fertilizers for soybeans [4-6]. On the other hand, fertilization with $\mathrm{N}$ is one of the most important factors in the management of corn due to losses of up to $44 \%$ of $\mathrm{N}-\mathrm{NH}_{3}$ through the ammonia volatilization process [7] when using urea as a top-dressing.

In this context, foliar fertilization in phenological stages R2 through R6 for soybean [8] and V13 through R1 for corn [2], appears as a complement and alternative to minimize $\mathrm{N}$ losses from traditional fertilization. Furthermore, there is great ease of application and relatively low costs, if foliar $\mathrm{N}$ application is performed concurrently with pesticide application.

Several studies have already been carried out with the application of different sources of $\mathrm{N}$, mainly urea $(45 \% \mathrm{~N})$ and urea-ammonium nitrate (UAN) $(32 \% \mathrm{~N})$ mixture of $50 \% \mathrm{NH}_{4} \mathrm{NO}_{3}$ and $50 \% \mathrm{CO}\left(\mathrm{NH}_{2}\right)_{2}$ [9]. However, few studies have tested the application of slow-release liquid nitrogen fertilizers in soybeans and corn under tropical and subtropical conditions.

According to Guelfi [10], slow-release fertilizers are products of condensation of urea with aldehydes in order to release the nutrient slower than conventional sources. Among the most used are urea formaldehyde (UF), methylene urea (UM), and isobutylidene-diurea (IBDU). UF slow-release fertilizers reduce the solubility of the $\mathrm{N}$ fractions present in their composition [11] by reacting under controlled conditions of $\mathrm{pH}$, temperature, molar ratio, and reaction time, forming polymer chains between formaldehyde carbon and urea [10]. The final product is a fertilizer with different molecular weights, degree of polymerization, and $\mathrm{N}$ solubility $[12,13]$.

The foliar application of nitrogen $(\mathrm{N})$ and other essential nutrients for plant growth and development is an important practice for agricultural production. Most of the traditional nitrogen leaf nutrients contained ammonium, nitrate, and/or urea, before sources of $\mathrm{N}$ based on urea-formaldehyde/ triazone were commercially on the market in liquid form [13-15].

Traditional sources of $\mathrm{N}$ have a higher rate of salinity, which increases the potential to burn the leaves of plants, making the use of these $\mathrm{N}$ sources more difficult [16]. Wesley and coworkers observed injuries to soybean leaves when UAN was applied, decreasing its yield [4]. To prevent or minimize leaf burning, $\mathrm{N}$-urea-triazone fertilizers can be used [16,17]. These fertilizers are formed by a controlled reaction with urea, formaldehyde, and ammonia [17], which according to the Association of American Plant Food Control Officials (AAPFCO) [18], must contain at least $25 \% \mathrm{~N}$ of the total. The triazone formed during the reaction must contribute at least $40 \%$ of the fertilizer $\mathrm{N}$ with the remaining $\mathrm{N}$ coming from urea and low molecular weight intermediate compounds derived from polymethylene urea.

According to Clapp and Paham [17], the application of $\mathrm{N}$ by means of slow-release foliar fertilizers with triazone presents characteristics of greater permanence on the surface of the leaves in the liquid phase, less potential for burning the leaves, and less loss by evaporation and volatilization, when compared to urea solution. In ${ }^{15} \mathrm{~N}$ isotope studies with different sources of $\mathrm{N}$, it was found that triazone was absorbed in an amount equal to or greater than that of urea, ammonium, and nitrate [16]. Kissel and Cabrea [19], working with urea-formaldehyde and triazone solution containing $38 \%$ of total $\mathrm{N}$ as urea, $57 \%$ as triazone, and $5 \%$ with side reaction products, found that this fertilizer was approximately four times more stable than a $100 \%$ urea-based solution in volatilization studies carried out in Kansas, USA. In their study, losses were $12.2 \%$ and 3.2\% for urea and urea-triazone, respectively, after four days [19].

Several studies have already been carried out with the application of different sources of $\mathrm{N}$ in soybean and corn crops $[2,7,20-24]$. However, there are few studies that have tested the application of liquid urea formaldehyde-triazone fertilizers in these crops. Thus, the objective of the study was to evaluate the effect of foliar application of urea and urea-formaldehyde, triazone-based fertilizers on soybean and corn crops. 


\section{Materials and Methods}

\subsection{Experimental Design, Treatments, and Crop Management}

The experiment during soybean season 2018/2019 was carried out at the Technology Diffusion Unit (UDT) of Cocamar Cooperativa Agroindustrial ( $23^{\circ} 35^{\prime} 33^{\prime \prime}$ S, $52^{\circ} 04^{\prime} 12^{\prime \prime}$ W), Floresta, Paraná State, Brazil. The experiment during corn season 2018/2019 and soybean season 2019/2020 were carried out at the Integrated University Center ( $23^{\circ} 98^{\prime} 82^{\prime \prime}$ S, $52^{\circ} 34^{\prime} 64^{\prime \prime}$ W), Campo Mourão, Paraná State, Brazil. The experiment during the corn second season was carried out at Sítio Santa Lúcia, $\left(24^{\circ} 05^{\prime} 36^{\prime \prime}\right.$, $51^{\circ} 41^{\prime} 85^{\prime \prime}$ W), Lunardeli, Paraná State, Brazil. These experiments were conducted in areas under no-tillage for more than 15 years, with previous cultivation of corn for the experimental areas of soybean (2018/2019 and 2019/2020), wheat for the experimental area of corn season (2018/2019), and soybean for the experimental area of corn second season (2019).

The soils of the experimental areas are classified as dystrophic Red Latosol [25], which corresponds to a Hapludox [26], and climate is classified as humid subtropical (Cfa) according to the Köppen-Geiger classification system [27]. The data for precipitation, temperature, and relative humidity of the air during the conduction of the experiments were obtained from INMET (Instituto Nacional de Meteorologia) and Instituto das Águas do Paraná, and are presented in Figure 1. Twenty samples were taken for chemical and particle size analysis of the soil (layer $0-20 \mathrm{~cm}$ ), to produce a composite sample. These results are described in Table 1.

Table 1. Chemical and physical characterization of the dystrophic Red Latosol (Hapludox) at a depth of $0-20 \mathrm{~cm}$ from soybean and corn experiments.

\begin{tabular}{ccccc}
\hline & \multicolumn{3}{c}{ Crops } \\
\cline { 2 - 5 } Soil Attributes & $\begin{array}{c}\text { Soybean } \\
\mathbf{2 0 1 8 - 2 0 1 9}\end{array}$ & $\begin{array}{c}\text { Soybean } \\
\mathbf{2 0 1 9 - 2 0 2 0}\end{array}$ & First Season Corn & Second Season Corn \\
\hline $\mathrm{pH} \mathrm{CaCl} \mathrm{Cl}_{2}$ & 4.90 & 5.20 & 5.20 & 5.15 \\
$\mathrm{H}+\mathrm{Al}\left(\mathrm{cmol}_{\mathrm{c}} \mathrm{dm}^{-3}\right)$ & 5.23 & 5.51 & 4.78 & 5.45 \\
$\mathrm{Al}^{3+}\left(\mathrm{cmol}_{\mathrm{c}} \mathrm{dm}^{-3}\right)$ & 0.00 & 0.00 & 0.00 & 0.00 \\
$\mathrm{Ca}^{2+}\left(\mathrm{cmol}_{\mathrm{c}} \mathrm{dm}^{-3}\right)$ & 2.98 & 3.73 & 5.58 & 6.44 \\
$\mathrm{Mg}^{2+}\left(\mathrm{cmol}_{\mathrm{c}} \mathrm{dm}^{-3}\right)$ & 1.39 & 1.59 & 1.52 & 1.31 \\
$\mathrm{~K}^{+}\left(\mathrm{cmol}_{\mathrm{c}} \mathrm{dm}^{-3}\right)$ & 0.24 & 0.50 & 0.44 & 0.55 \\
$\mathrm{SB}\left(\mathrm{cmol}_{\mathrm{c}} \mathrm{dm}^{-3}\right)$ & 4.61 & 5.82 & 7.54 & 8.30 \\
$\mathrm{CEC}\left(\mathrm{cmol}_{\mathrm{c}} \mathrm{dm}^{-3}\right)$ & 9.84 & 11.33 & 12.31 & 13.75 \\
$\mathrm{BS}(\%)$ & 47 & 51 & 61 & 60 \\
$\mathrm{P}\left(\mathrm{g} \mathrm{dm}^{-3}\right)$ & 14.11 & 21.72 & 7.42 & 13.39 \\
$\mathrm{~B}\left(\mathrm{~g} \mathrm{dm}^{-3}\right)$ & 1.72 & 0.20 & 0.47 & 0.20 \\
$\mathrm{OC}\left(\mathrm{g} \mathrm{dm}^{-3}\right)$ & 26.03 & 23.87 & 22.45 & 18.74 \\
OM $(\%)$ & 2.60 & 2.38 & 2.24 & 1.87 \\
Sand $(\%)$ & 18 & 18 & 18 & 18 \\
Silt $(\%)$ & 6 & 10 & 10 & 16 \\
$\mathrm{Clay}(\%)$ & 76 & 72 & 66 \\
\hline
\end{tabular}

$\mathrm{pH} \mathrm{CaCl}_{2}(0.01 \mathrm{M}) ; \mathrm{H}+\mathrm{Al}$ was extracted by using the SMP method; $\mathrm{Ca}, \mathrm{Mg}$, and $\mathrm{Al}$ contents were extracted by $\mathrm{KCl}$ $1 \mathrm{~mol} \mathrm{~L}-1$; $\mathrm{P}$ and $\mathrm{K}$ contents were extracted by Mehlich-1; SB: sum of bases $(\mathrm{Ca}+\mathrm{Mg}+\mathrm{K})$; $\mathrm{CEC}$ : cation exchange capacity $(\mathrm{SB}+\mathrm{H}+\mathrm{Al})$; \%BS: percent base saturation $[(\mathrm{SB} / \mathrm{CEC}) \times 100]$; total $\mathrm{C}$ content was determined by using Walkley and Black method; B was extracted with hot water and soil texture: densimeter method. 

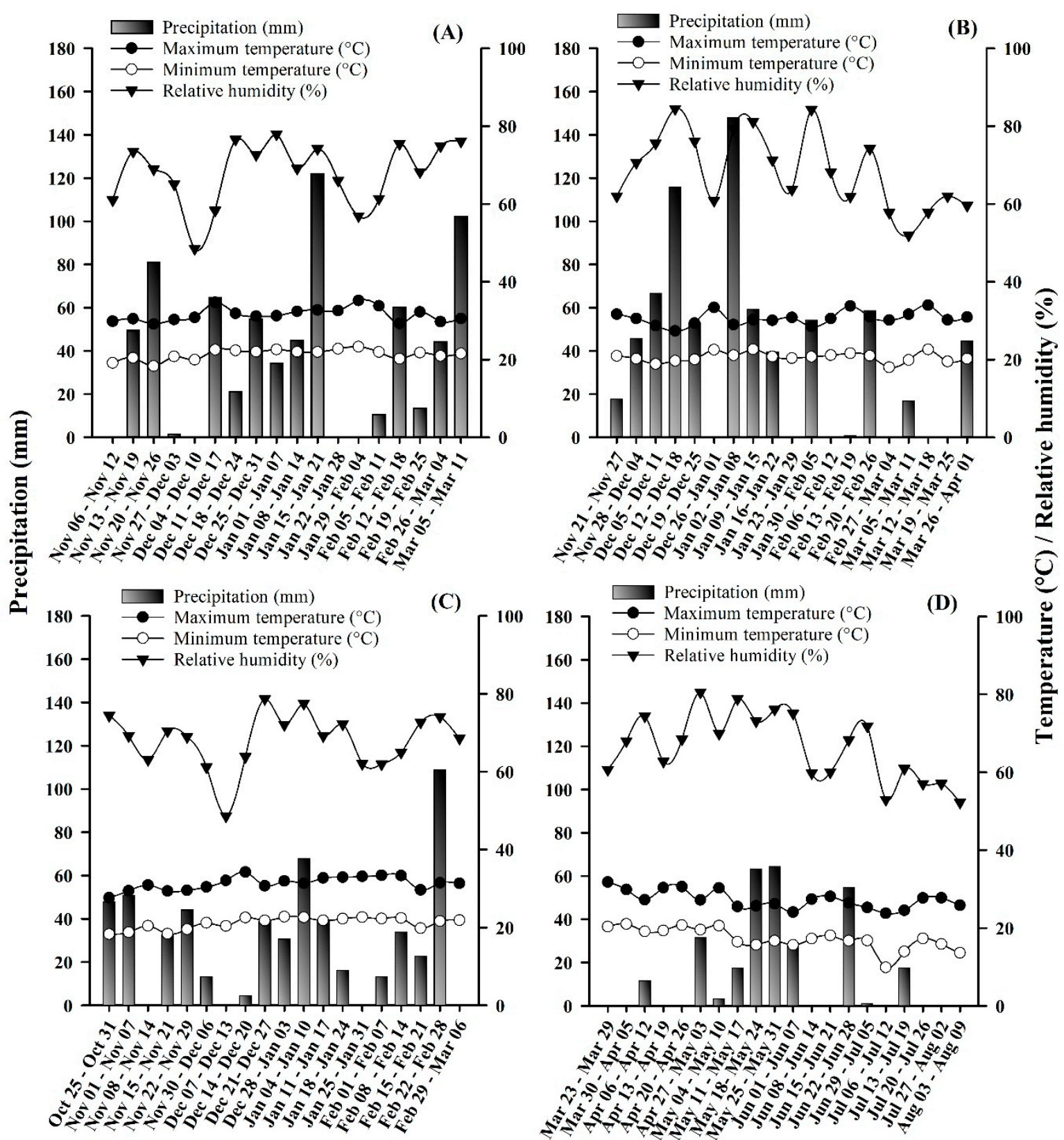

Figure 1. Precipitation, minimum and maximum temperature, and relative humidity of the air for soybean season 2018/2019 (A), soybean season 2019/2020 (B), corn first season 2018/2019 (C), and corn second season 2019 (D).

The experimental design used was a randomized block, with 5 treatments with 5 replications studied. The treatments consisted of a control without application of foliar N (T1), a conventional urea solution (T2), Hexion ${ }^{\circledR} 1$ nitrogen fertilizer with $28 \% \mathrm{~N}$ and $70 \%$ slow-release compounds (T3), Hexion ${ }^{\circledR} 2$ nitrogen fertilizer with $26 \% \mathrm{~N}$ and $60 \%$ slow-release compounds (T4), and Hexion ${ }^{\circledR} 3$ nitrogen fertilizer with $24.5 \% \mathrm{~N}+0.5 \% \mathrm{~B}+0.3 \%$ Mo with $55 \%$ slow-release compounds (T5).

The experimental units were composed of 8 rows of $10 \mathrm{~m}$ in length spaced $0.45 \mathrm{~m}$ apart, totaling $36 \mathrm{~m}^{2}$. The treatments were applied at the phenological stage R2 (full bloom) for soybean and V13 (thirteen-leaf) for first season corn and second season corn. The dose used was $10 \mathrm{~L} \mathrm{ha}^{-1}$, using a backpack sprayer pressurized with $\mathrm{CO}_{2}$, with empty cone Jacto ${ }^{\circledR}$ ATR nozzles manufactured in Brazil in the state of São Paulo, regulated to 75 psi working pressure, and a flow rate of $120 \mathrm{~L} \mathrm{ha}^{-1}$. 
Two harvests were evaluated for soybean, with sowing carried out on 6 November 2018 and 11 November 2019, using cultivars of the same physiological maturation group BMX Garra IPRO and Corteva 6215, respectively. Basic fertilization consisted of $300 \mathrm{~kg} \mathrm{ha}^{-1}$ of $02-20-18\left(\mathrm{~N}-\mathrm{P}_{2} \mathrm{O}_{5}-\mathrm{K}_{2} \mathrm{O}\right)$. In the corn crop, two crops were evaluated: one of first season corn and the other of second crop corn, sown on 25 October 2018 and 23 March 2019, using the hybrid Pioneer P30F53 VYHR for the summer harvest (first season corn) and Morgan 30A37 for the winter harvest (second season corn), and basic fertilization of $300 \mathrm{~kg} \mathrm{ha}^{-1}$ of $10-15-15\left(\mathrm{~N}-\mathrm{P}_{2} \mathrm{O}_{5}-\mathrm{K}_{2} \mathrm{O}\right)$ and $500 \mathrm{~kg} \mathrm{ha}^{-1}$ of $13-24-12\left(\mathrm{~N}-\mathrm{P}_{2} \mathrm{O}_{5}-\mathrm{K}_{2} \mathrm{O}\right)$, respectively. Top-dressing $\mathrm{N}$ fertilization was applied at a dose of $200 \mathrm{~kg} \mathrm{ha}^{-1}$ of $\mathrm{N}$ divided at phenological stages V4 $\left(100 \mathrm{~kg} \mathrm{ha}^{-1}\right)$ and V6 $\left(100 \mathrm{~kg} \mathrm{ha}^{-1}\right)$ for first season corn. Second season corn was fertilized with $65 \mathrm{~kg} \mathrm{ha}^{-1}$ of $\mathrm{N}$ top-dressing at phenological stage $\mathrm{V} 4$, as recommended in the Paraná State Fertilization and Liming Manual [28].

\subsection{N Status of the Soybean, Corn, and Yield Components}

The $\mathrm{N}$ status of soybeans was assessed by randomly collecting the third fully developed leaf, from top to bottom on the main stem. For corn, the middle third of the first opposite leaf below the ear was collected [28]. Collection of samples was accomplished at phenological stage R4 for both cultivars, with the purpose of evaluating the N content after the application of the treatments. After sampling, the leaves were washed in distilled and deionized water and dried in an oven with forced air circulation at $65^{\circ} \mathrm{C}$ for $72 \mathrm{~h}$. Subsequently, the materials were ground in a Willey mill, weighed, and subjected to sulfuric digestion to determine leaf $\mathrm{N}$ content using the Kjeldahl method [29].

In the phenological stage R6 for soybean, 5 plants per experimental unit were sampled at random in order to obtain the yield components of soybean pods with 1, 2, and 3 grains (POD 1, POD 2, and POD 3), as well as the total number of pods per plant (NPP) and number of grains per plant (NGP). When soybean and corn showed physiological maturation at stage R8 and R6, respectively, the harvest was carried out on 9 March 2019 and 27 March 2020 for soybean 2018-2019 and 2019-2020, respectively. For corn, harvests proceeded on 7 March 2019 and 5 August 2019 for first season corn and second season corn, respectively. The area harvested was $8 \mathrm{~m}$ from the three central rows of each plot, totaling $10.8 \mathrm{~m}^{2}$ of usable area. After harvesting, the moisture content of the grains was corrected to $13 \%$ and yield calculated in $\mathrm{kg} \mathrm{ha}^{-1}$. After this evaluation, 50 grains were selected at random from each plot and weighed three times to determine the variable mass per thousand grains (TMG).

The components of corn yield were evaluated after harvesting at the physiological maturation stage R6, with the number of rows per ear (NR), number of grains per row (NGR), and number of grains per ear (NGC) estimated. For these estimates, 10 ears were selected at random from the useful plot area.

\subsection{Statistical Analysis}

The data obtained were subjected to homogeneity of variance (Bartlett) and error normality (Shapiro-Wilk) tests, thus meeting the assumptions for analysis of variance [30]. Subsequently, the data were subjected to analysis of variance and their means compared using the Scott-Knott test $(\alpha=0.1)$, using SISVAR 5.6 statistical software. Analysis using Pearson's linear correlation was conducted using the software R 3.6.3 (R Development Core Team).

\section{Results and Discussion}

Climatic conditions were generally favorable to the development of crops, apart from second season corn grown in 2019 (Figure 1). For the soybean crop, the accumulated precipitation was 705 and $722 \mathrm{~mm}$ for the years 2018-2019 (Figure 1A) and 2019-2020 (Figure 1B), respectively, with volumes of 450-800 mm meeting the water requirement of the crop, depending upon rain distribution during the plant cycle and cycle length of cultivars [31]. Despite the accumulated precipitation having met the total soybean water requirement, only $10.8 \mathrm{~mm}$ accumulated between the phenological stages R4 (pod fully developed) and R5 (grain filling) for the 2018-2019 season (Figure 1A) in the period from 
January 22 to February 11. According to Farias et al. [32], the need for water in soybean crops increases with the development of the plant, reaching its maximum need of 7 to $8 \mathrm{~mm}^{\text {day }}{ }^{-1}$ during grain filling and then decreasing afterward. Thus, the water availability in this period could have been less than demand, negatively affecting yield.

For corn, rainfall accumulations of 569 and $296 \mathrm{~mm}$ were recorded for the first crop (Figure 1C) and second crop (Figure 1D), respectively. In this case, water needs were not met for second crop corn (Figure 1D). The findings of Fancelli [33], suggest that corn requires $400-600 \mathrm{~mm}$ of precipitation to meet its production potential.

Regarding the number of grains per pod (POD 1, POD 2, and POD 3) and number of total pods per plant (NPP), significant statistical differences were observed in their averages for the 2018-2019 soybean season (Table 2). The treatments Hexion 2 and Hexion 3 were superior to Hexion 1, urea solution, and control for POD 1 and POD 2. Conversely, POD 3 varied from 19.7 to 27.1 pods, with all treatments of Hexion 1, Hexion 2, and Hexion 3 statistically superior to the urea solution, as well as the control treatments. For number of pods per plant (NPP) and number of grains per plant (NGP), all treatments based on urea-formaldehyde/triazone $\mathrm{N}$ Hexion 1, Hexion 2, and Hexion 3, were statistically superior to the treatments with urea and the control (Table 2).

Table 2. Average data of pod one grain (POD 1), pod two grain (POD 2), pod three grain (POD 3), number pod per plant (NPP), number of grain per plant (NGP), leaf nitrogen (LN), thousand mass grains (TMG), and yield, as a function of treatments in soybean year 2018-2019 and 2019-2020.

\begin{tabular}{|c|c|c|c|c|c|c|c|c|c|c|}
\hline Treatments & Year & Pod 1 & Pod 2 & Pod 3 & NPP & NGP & $\begin{array}{c}\text { LN } \\
\mathrm{g} \mathrm{kg}^{-1}\end{array}$ & $\begin{array}{c}\text { TMG } \\
\mathrm{g}\end{array}$ & $\begin{array}{c}\text { Yield } \\
\text { kg ha }^{-1}\end{array}$ & $\begin{array}{l}\text { Increase in Yield in } \\
\text { Relation } \\
\text { to the Control (\%) }\end{array}$ \\
\hline Control & $18 / 19$ & $4.7 \mathrm{~b}$ & $12.5 \mathrm{~b}$ & $19.7 \mathrm{~b}$ & $37.0 \mathrm{~b}$ & $88.9 \mathrm{~b}$ & $44.6 \mathrm{a}$ & $129.5 \mathrm{a}$ & $2618 b$ & _ \\
\hline Urea & $18 / 19$ & $4.3 \mathrm{~b}$ & $10.2 \mathrm{~b}$ & $17.6 \mathrm{~b}$ & $32.1 \mathrm{~b}$ & $77.6 \mathrm{~b}$ & $41.9 \mathrm{a}$ & $123.4 \mathrm{a}$ & 2496 b & $-\overline{4} .6$ \\
\hline Hexion 1 & $18 / 19$ & $4.2 \mathrm{~b}$ & $13.0 \mathrm{~b}$ & $25.3 \mathrm{a}$ & $42.5 \mathrm{a}$ & $106.3 \mathrm{a}$ & $39.4 \mathrm{~b}$ & $122.4 \mathrm{a}$ & $2646 \mathrm{~b}$ & 1.0 \\
\hline Hexion 2 & $18 / 19$ & $6.3 \mathrm{a}$ & $15.4 \mathrm{a}$ & $22.5 \mathrm{a}$ & $44.2 \mathrm{a}$ & $104.7 \mathrm{a}$ & $38.9 \mathrm{~b}$ & $121.5 \mathrm{a}$ & $2869 a$ & 9.6 \\
\hline Hexion 3 & $18 / 19$ & $6.6 \mathrm{a}$ & $16.1 \mathrm{a}$ & $27.1 \mathrm{a}$ & $49.9 \mathrm{a}$ & $120.2 \mathrm{a}$ & $40.2 \mathrm{~b}$ & $128.1 \mathrm{a}$ & 3003 a & 14.7 \\
\hline Control & $19 / 20$ & $7.8 \mathrm{a}$ & $19.7 \mathrm{a}$ & $21.5 \mathrm{a}$ & $49.1 \mathrm{a}$ & $112.0 \mathrm{a}$ & $57.4 \mathrm{a}$ & $137.2 \mathrm{a}$ & $3112 \mathrm{a}$ & - \\
\hline Urea & $19 / 20$ & $9.4 \mathrm{a}$ & $21.9 \mathrm{a}$ & $24.1 \mathrm{a}$ & $55.5 \mathrm{a}$ & $125.8 \mathrm{a}$ & $57.9 \mathrm{a}$ & $142.0 \mathrm{a}$ & $3190 \mathrm{a}$ & 2.5 \\
\hline Hexion 1 & $19 / 20$ & $7.8 \mathrm{a}$ & $19.5 \mathrm{a}$ & $22.5 \mathrm{a}$ & $49.8 \mathrm{a}$ & $114.4 \mathrm{a}$ & $55.9 \mathrm{a}$ & $139.9 \mathrm{a}$ & $3091 \mathrm{a}$ & -0.6 \\
\hline Hexion 2 & $19 / 20$ & $8.4 \mathrm{a}$ & $20.4 \mathrm{a}$ & $25.0 \mathrm{a}$ & $53.9 \mathrm{a}$ & $124.3 \mathrm{a}$ & $57.4 \mathrm{a}$ & $142.3 \mathrm{a}$ & $3283 a$ & 5.5 \\
\hline Hexion 3 & $19 / 20$ & $8.3 \mathrm{a}$ & $21.2 \mathrm{a}$ & $25.5 \mathrm{a}$ & $55.1 \mathrm{a}$ & $127.4 \mathrm{a}$ & $57.9 \mathrm{a}$ & $136.9 \mathrm{a}$ & $3267 \mathrm{a}$ & 5.0 \\
\hline
\end{tabular}

In the column, means followed by the same letter do not differ, through the Scott-Knott test (10\%).

According to Moreira et al. [22], working with yield and response of the $\mathrm{N}$ status of the soybean crop through the foliar application of $10 \mathrm{~L} \mathrm{ha}^{-1}$ of $\mathrm{N}$ at the phenological stage R3 (beginning of pod formation), no significant differences were found for total pods per plant (NPP), using urea solution $\mathrm{CO}\left(\mathrm{NH}_{2}\right)_{2}$, corroborating the results of the present work. For the 2019-2020 soybean crop, no significant differences were observed for POD 1, POD 2, POD 3, NPP, and NGP, as described in Table 2.

Regarding corn, no statistically significant difference was observed in the yield components of the crop (Table 3), apart from number of rows (NR) and mass of a thousand grains (TMG) of the second crop corn grown in 2019 (Table 3). The Hexion 1 treatment was statistically superior to the other treatments, and the urea solution and Hexion 2 were superior to the control without application of $\mathrm{N}$ and to Hexion 3 for the NR variable (Table 3). With respect to the influence of application times and nitrogen sources in top-dressing in second crop corn under no-tillage, Kappes et al. [20] observed that the application of nitrogen provided a greater number of grain rows per ear, regardless of the nitrogenous source.

The levels of $\mathrm{N}$ in soybean leaves (LN) ranged from 38.9 to 44.6 and 55.9 to $57.9 \mathrm{~g} \mathrm{~kg}^{-1}$ for the 2018-2019 and 2019-2020 seasons, respectively (Table 2). However, only the 2018-2019 soybean crop showed a statistically significant difference. The leaves were collected in the phenological stage R4 due to the application of treatments that were carried out in R3. This made it difficult to compare with the standard values of $\mathrm{N}$ in the leaf for adequate levels in R2, as suggested by the Manual of Fertilization and Liming for the State of Paraná, which is from 45 to $61 \mathrm{~g} \mathrm{~kg}^{-1}$ of N [28]. 
Table 3. Average data of number of rows (NR), number of grains per row (NGR), number of grains per cob (NGC), leaf nitrogen (LN), thousand mass grain (TMG), and yield, as a function of treatments in first season corn 2018-2019 and second season corn 2019.

\begin{tabular}{|c|c|c|c|c|c|c|c|c|}
\hline Treatments & Year & NR & NGR & NGC & $\begin{array}{c}\mathrm{LN} \\
\mathrm{g} \mathrm{kg}^{-1}\end{array}$ & $\begin{array}{c}\text { TMG } \\
\mathrm{g}\end{array}$ & $\begin{array}{c}\text { Yield } \\
\text { kg ha }^{-1}\end{array}$ & $\begin{array}{c}\text { Increase in Yield in Relation } \\
\text { to the Control }(\%)\end{array}$ \\
\hline Control & $18 / 19$ & $11.9 \mathrm{a}$ & $22.0 \mathrm{a}$ & $263.2 \mathrm{a}$ & $25.3 \mathrm{a}$ & 415.7 a & $5854 \mathrm{a}$ & - \\
\hline Urea & $18 / 19$ & $12.3 \mathrm{a}$ & $22.4 \mathrm{a}$ & $279.4 \mathrm{a}$ & $25.1 \mathrm{a}$ & $400.0 \mathrm{a}$ & 7075 a & 20.8 \\
\hline Hexion 2 & $18 / 19$ & $12.7 \mathrm{a}$ & $23.4 \mathrm{a}$ & $299.2 \mathrm{a}$ & $24.9 \mathrm{a}$ & $391.5 \mathrm{a}$ & 7768 a & 32.7 \\
\hline Hexion 3 & $18 / 19$ & $12.9 \mathrm{a}$ & $25.0 \mathrm{a}$ & 327.0 a & $25.8 \mathrm{a}$ & 396.7 a & 7897 a & 34.9 \\
\hline Hexion 1 & 2019 & $16.3 \mathrm{a}$ & $35.2 \mathrm{a}$ & $575.6 \mathrm{a}$ & $26.7 \mathrm{a}$ & $330.6 \mathrm{a}$ & $5314 \mathrm{a}$ & 2.6 \\
\hline Hexion 2 & 2019 & $16.0 \mathrm{~b}$ & $34.5 \mathrm{a}$ & $552.0 \mathrm{a}$ & $27.5 \mathrm{a}$ & $308.0 \mathrm{~b}$ & $5292 \mathrm{a}$ & 2.2 \\
\hline Hexion 3 & 2019 & $15.3 \mathrm{c}$ & $36.5 \mathrm{a}$ & $559.6 \mathrm{a}$ & $26.9 \mathrm{a}$ & $305.6 \mathrm{~b}$ & $5370 \mathrm{a}$ & 3.7 \\
\hline
\end{tabular}

In the column, means followed by the same letter do not differ, through the Scott-Knott test (10\%).

Taking these values as a standard, only the treatment without application of $\mathrm{N}$ (control) showed a value within the range considered appropriate, which was $44.6 \mathrm{~g} \mathrm{~kg}^{-1}$ of $\mathrm{N}$. The treatments that presented the highest levels of LN were the control and the treatment with urea solution (Table 2), which statistically surpassed all treatments based on urea-formaldehyde. This fact may have occurred due to the effect of diluting $\mathrm{N}$ on the leaves by greater translocation of $\mathrm{N}$ to a greater number of sinks generated (NPP) in the urea-formaldehyde/triazone treatments [34].

Although urea is considered the most suitable source of $\mathrm{N}$ for foliar application due to its nonpolarity, rapid absorption, and high solubility $[35,36]$, several studies have shown that there is no significant difference in absorption between urea and other nitrogen sources for foliar applications $[37,38]$. For first season 2018-2019 and second season 2019 corn, no significant differences in LN levels were observed with ranges from 24.7 to $25.8 \mathrm{~g} \mathrm{~kg}^{-1}$ and 25.6 to $27.5 \mathrm{~g} \mathrm{~kg}^{-1}$, respectively (Table 3). Other studies with three forms of foliar fertilizers containing nitrogen did not observe a statistical difference in LN levels in corn [39]. Likewise, the same observation was made for tomato crops [16].

The mass per thousand grains (TMG) measurement for the 2018-2019 and 2019-2020 soybean crops did not demonstrate a significant difference between the average of the treatments, ranging from 121.5 to $129.5 \mathrm{~g}$ and 137.2 to $142.3 \mathrm{~g}$, respectively (Table 2). These results agree with those obtained by Moreira et al. [22] while studying the foliar application of $\mathrm{N}$ through different nitrogen sources in soybean culture with no significant effect on TMG observed. However, for yield during the 2018-2019 soybean season, the treatments based on urea-formaldehyde/triazone Hexion 2 and Hexion 3 demonstrated statistically superior performance compared to treatments Hexion 1 , urea solution, and the control (Table 2), providing interesting results from an agronomic point of view. Kotz-Gurgacz and coworkers, working with foliar application of urea formaldehyde in the state of São Paulo, also observed a significant increase in yield of $15.6 \%$ in the bean crop in comparison to the control [40]. When analyzing Pearson's linear correlation for the 2018-2019 soybean crop, it is observed that production showed a positive correlation of $0.36,0.35$, and 0.36 for POD 1, POD 2, and NPP, respectively (Figure 2). These are components that contributed significantly to the increase in yield.

A study in Paraná state with increasing applications of nitrogen foliar fertilizer with enhanced-efficiency fertilizer in the phenological stages of soybean, observed a quadratic response when foliar fertilizer was applied in R1 (beginning flowering) and R4 (full pod), which provided a significant increase in yield of 338 and $296 \mathrm{~kg} \mathrm{ha}^{-1}$ of soybean, respectively [2]. In the current experiment, the significant increase in yield in relation to the treatment without application of foliar $\mathrm{N}$ for the 2018-2019 soybean crop (Table 2) was 251.2 and $384.6 \mathrm{~kg} \mathrm{ha}^{-1}$ for Hexion 2 and Hexion 3, respectively. These values compare closely to those found by Pacentchuk et al. [2] in an experiment also carried out in the state of Paraná. 


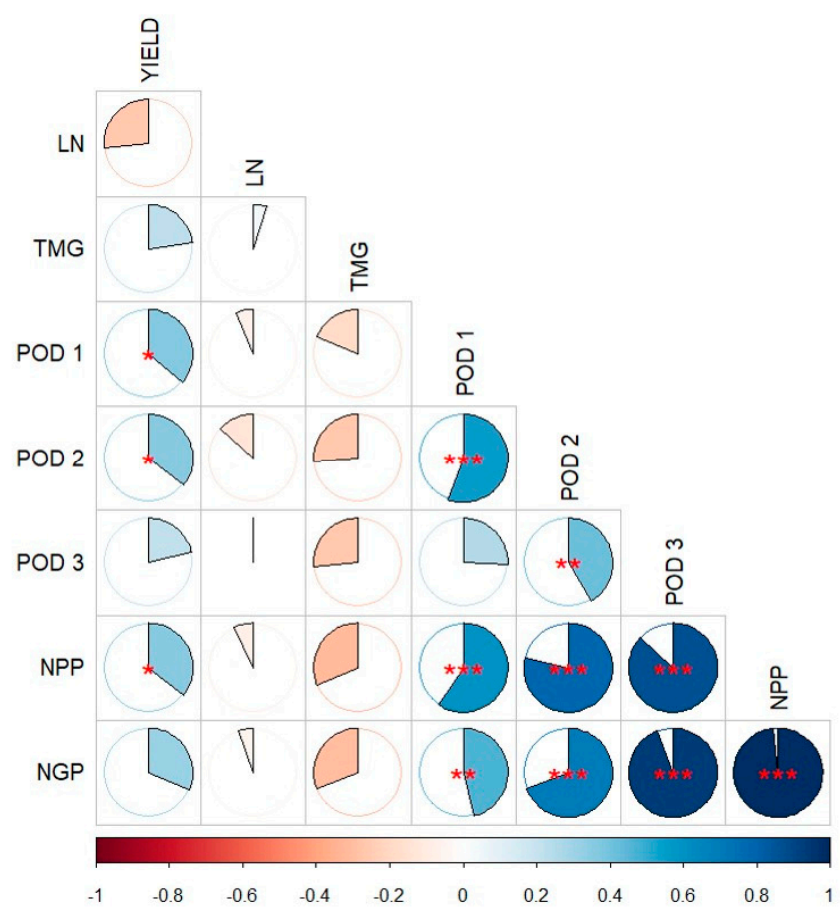

Figure 2. Pearson linear correlation matrix between soybean yield components for the year 2018-2019: pod one grain (POD 1), pod two grain (POD 2), pod three grain (POD 3), number pod per plant (NPP), number of grain per plant (NGP), leaf nitrogen (LN), thousand mass grains (TMG), and yield. Note: ${ }^{*}$ significant at $10 \%,{ }^{* *}$ significant at $5 \%,{ }^{* * *}$ significant at $1 \%$.

The slow-release nitrogen liquid fertilizers (N-Hexion ${ }^{\circledR}$ ) showed a significant increase in yield in comparison to 15 and 20\% urea solution for Hexion 2 and Hexion 3, respectively. This occurs, according to Clapp and Parham [17], because the application of $\mathrm{N}$ by means of foliar slow-release fertilizers with triazone enables characteristics of greater permanence on the surface of the leaves in the liquid phase with less potential for burning the leaves and less loss by evaporation and volatilization when compared with urea solution. In the best treatment, Moreira et al. [22] observed that foliar fertilization with urea increased soybean (2018/2019) yield by $8.6 \%$ when compared to the control. This was lower than the value obtained by the present work in which the treatments Hexion 2 and Hexion 3 the urea-formaldehyde/triazone base showed 9.6 and 14.7\% increase, respectively, in soybean yield when compared to the control.

Notice that Hexion 1 showed no statistical difference for productivity compared to the control and urea solution in the 2018-2019 soybean season (Table 2). It can be observed that Hexion 1 has a high proportion of $70 \%$ slow-release $\mathrm{N}$ compounds, contributing to a lower nitrogen absorption by the plant, unlike the Hexion 2 and Hexion 3 treatments that have slow-release proportions of 60 and $55 \%$ respectively. Nitrogen fertilizers with high percentages of slow-release compounds promote nitrogen release more slowly due to reduced solubility of $\mathrm{N}$ fractions, resulting from the formation of long polymer chains between carbon formaldehyde and urea [11-14]. The proportion of slow-release $\mathrm{N}$ compounds and soluble $\mathrm{N}$ is important to achieve high yields in soybeans and corn, since both crops develop in only a few months.

The same did not happen for the 2019-2020 soybean crop as the treatments did not show a significant difference in their averages (Table 2). Although no statistical difference was observed for the 2019-2020 soybean crop, Hexion 2 and Hexion 3 promoted an average increase of 5.2\% in comparison to the control (Table 2). According to Câmara [41], the increase in nodulation reaches a first peak at full flowering, R1 to R2, in response to the first peak of photosynthetic activity occurring at the beginning of flowering. As fruiting evolves, photosynthetic activity increases and more carbon is fixed through a 
second photosynthesis peak between stages R4 and R5.1. Part of this is sent to the roots as a result of a second nodulation peak and biological nitrogen fixation (BNF) between stages R5.1 and R5.3.

If water stress occurs at this stage, this negatively affects the formation of nodules and BNF, decreasing the size of the nodules and reducing their activity [42-44]. This may have led to a significant response to $\mathrm{N}$ foliar fertilization of the 2018-2019 soybean crop, as a result of supplying the need for $\mathrm{N}$ once BNF was compromised.

Regarding corn culture, the TMG, an important yield component, was not influenced by the fertilization of foliar N for corn first season 2018-2019 (Table 3). This corroborates other research findings $[20,21,45,46]$ which studied the nitrogen top-dressing management in corn crops under no-tillage. According to Borrás and Otegui [47], this is the production component least affected by variations in management and fertilization practices.

For the second season corn, the treatments composed of Hexion 1, urea solution, and control showed means statistically superior to the treatments Hexion 2 and Hexion 3, for the variable TMG (Table 3). In general, an increase in NGC results in a corresponding decrease in TMG. This can explain part of the decrease in TMG for corn in the treatments that received the application of foliar formaldehyde-urea/triazone (i.e., Hexion 2 and Hexion 3).

For corn yield (Table 3), the first season crop 2018-2019 and the second season crop 2019, neither harvest showed statistical difference between their averages. This corroborates the results obtained by Kappes et al. [21] who, studying agronomic performance of corn grown under no-tillage, did not observe significant differences in yield with foliar application of $\mathrm{N}$. Although no statistical difference was observed for the first season corn 2018-2019, the solution of urea, Hexion 1, Hexion 2, and Hexion 3 promoted increases of 20.8, 29.5, 32.7, and 34.9\%, respectively, in comparison to the control (Table 3). On average, the use of $\mathrm{N}$ foliar fertilizers increased corn yield by approximately $24 \%$.

For corn second crop 2019, there was no significant difference in yield when compared to first season corn 2018-2019 (Table 3). This was due to the limitations imposed during the second season corn caused by the decrease in temperature, light, and precipitation [48]. In this case, water requirements were not met for second season corn (Figure 1D) with accumulated rainfall of only $296 \mathrm{~mm}$. Corn cultivation requires a volume of $400-600 \mathrm{~mm}$ of precipitation to meet yield expectations [33]. Although no statistical difference was observed for the second season corn 2019, Hexion 1, Hexion 2, and Hexion 3 promoted increases ranging from 2.2 to $3.7 \%$ in relation to the control (Table 3).

Regarding the foliar application of $\mathrm{N}$, the different responses are quite divergent in the literature, which is probably due to the different cultivars used, edaphoclimatic conditions, and the different sources of $\mathrm{N}$. However, it is worth considering that in this work, the application of foliar $\mathrm{N}$ aims to complement the $\mathrm{N}$ applied via base and top-dressing, so that it is possible to supply cultivars with a high yield potential, and to supply possible nutrient deficiencies in the grain filling phase due to losses, mainly due to volatilization.

\section{Conclusions}

Foliar application of urea-formaldehyde/triazone, showed a significant difference in yield components POD 1, POD 2, POD 3, NPP, and NGP, which led to a significant increase in yield in soybean 2018-2019, in comparison to the control and urea conventional, 9.6 and 14.7\%, and 15.0 and $20.0 \%$ for Hexion 2 and Hexion 3, respectively.

Foliar application based on conventional urea showed no statistically significant difference in comparison to the control without application of foliar $\mathrm{N}$ for the yield components POD 1, POD 2, POD 3, NPP, NGP, TMG, and grain yield for the soybean crops of 2018-2019 and 2019-2020.

Nitrogen fertilizers with high percentages of slow-release compounds, such as Hexion 1, promote the release of nitrogen more slowly, due to the reduction of the solubility of the $\mathrm{N}$ fractions, contributing to a lower nitrogen absorption by the plants, which led to no significant increase in yield for Hexion 1 .

No statistical differences were observed in the yield of corn first and second season, with foliar application of conventional urea or with enhanced-efficiency fertilizer. 
Author Contributions: Conceptualization, B.M.A.R.C., A.P.M.M., D.F., F.R.M., É.J.D.O.Z., and M.A.B.; methodology, B.M.A.R.C., A.P.M.M., F.R.M., É.J.D.O.Z., and M.A.B.; validation, B.M.A.R.C., A.P.M.M., D.F., F.R.M., ÉJ.D.O.Z., and M.A.B.; investigation, B.M.A.R.C., É.J.D.O.Z., and M.A.B.; resources, B.M.A.R.C., A.P.M.M., D.F., F.R.M., É.J.D.O.Z., and M.A.B.; data collection, B.M.A.R.C., É.J.D.O.Z., and M.A.B.; data analysis, B.M.A.R.C.; writing-original draft preparation, B.M.A.R.C; writing-review and editing, B.M.A.R.C., F.R.M., and M.A.B.; visualization, B.M.A.R.C., A.P.M.M., D.F., F.R.M., É.J.D.O.Z., and M.A.B.; supervision, M.A.B. All authors have read and agreed to the published version of the manuscript.

Funding: Coordenação de Aperfeiçoamento de Pessoal de Nível Superior (In Portuguese) (CAPES- 88887. 482759/2020-00).

Acknowledgments: The authors thank Hexion Inc. and Grupo de Estudos em Solos da Universidade Estadual de Maringá-GESSO-UEM (in Portuguese).

Conflicts of Interest: The authors declare no conflict of interest.

\section{References}

1. World Agricultural Production, 2020. USDA Foreign Agricultural Service. Available online: https: //apps.fas.usda.gov/psdonline/circular/production.pdf (accessed on 7 July 2020).

2. Pacentchuk, F.; Novakowiski, J.H.; Novakowlskl, J.H.; Sandlnl, I.E. Nitrogênio complementar via foliar nas culturas do milho, soja e feijão: Doses e estádios fenológicos de aplicação. Rev. Plantio Direto 2014, 142/143, 28-34.

3. Hungria, M.; Campo, R.J.; Mendes, I.C. Fixação Biológica do Nitrogênio na Cultura da soja; Circular Técnica/ Embrapa Soja: Londrina, Brazil, 2001; p. 48.

4. Wesley, T.L.; Lamond, R.E.; Martin, V.L.; Duncan, S.R. Effects of Late-Season Nitrogen Fertilizer on Irrigated Soybean Yield and Composition. J. Prod. Agric. 1998, 11, 331-336. [CrossRef]

5. Lamond, R.E.; Wesley, T.L. Adubação nitrogenada no momento certo para soja de alta produtividade. Inform. Agron. 2001, 95, 6-7.

6. Salvagiotti, F.; Specht, J.; Cassman, K.G.; Walters, D.T.; Weiss, A.; Dobermann, A. Growth and Nitrogen Fixation in High-Yielding Soybean: Impact of Nitrogen Fertilization. Agron. J. 2009, 101, 958-970. [CrossRef]

7. Minato, E.A.; Cassim, B.M.A.R.; Besen, M.R.; Mazzi, F.L.; Inoue, T.T.; Batista, M.A. Controlled-release nitrogen fertilizers: Characterization, ammonia volatilization, and effects on second-season corn. Rev. Bras. Ciênc. Solo 2020, 44, 0190108. [CrossRef]

8. Freeborn, J.R.; Holshouser, D.L.; Alley, M.M.; Powell, N.L.; Orcutt, D.M. Soybean Yield Response to Reproductive Stage Soil-Applied Nitrogen and Foliar-Applied Boron. Agron. J. 2001, 93, 1200-1209. [CrossRef]

9. Otto, R.; Júnior, J.C.M.D.F.; Zavaschi, E.; De Faria, I.K.P.; Paiva, L.A.; Bazani, J.H.; De Mira, A.B.; Kamogawa, M.Y. Combined Application of Concentrated Vinasse and Nitrogen Fertilizers in Sugarcane: Strategies to Reduce Ammonia Volatilization Losses. Sugar Tech 2016, 19, 248-257. [CrossRef]

10. Guelfi, D. Fertilizantes nitrogenados estabilizados, de liberação lenta ou controlada. Inform. Agron. 2017, 157, 1-32.

11. Neyman, G.; Derr, E. Homogeneous Granules of slow-Release Fertilizer and Method of Making the Same. U.S. Patent 6.464.746 B2, 15 October 2002.

12. Jahns, T.; Ewen, H.; Kaltwasser, H. Biodegradability of Urea-Aldehyde Condensation Products. J. Polym. Environ. 2003, 11, 155-159. [CrossRef]

13. Yamamoto, C.F.; Pereira, E.I.; Mattoso, L.H.; Matsunaka, T.; Ribeiro, C. Slow release fertilizers based on urea/urea-formaldehyde polymer nanocomposites. Chem. Eng. J. 2016, 287, 390-397. [CrossRef]

14. Trenkel, M.E. Slow and Controlled-Release and Stabilized Fertilizers: An Option for Enhancing Nutrient Use Efficiency in Agriculture, 2nd ed.; International Fertilizer Industry Association: Paris, France, 2010; p. 160.

15. Azeem, B.; KuShaari, K.; Man, Z.B.; Basit, A.; Thanh, T.H. Review on materials \& methods to produce controlled release coated urea fertilizer. J. Control. Release 2014, 181, 11-21. [CrossRef] [PubMed]

16. Widders, I.E. Absorption and translocation of foliar applied triazone-n as compared to other nitrogen sources in tomato. J. Plant Nutr. 1991, 14, 1035-1045. [CrossRef]

17. Clapp, J.G.; Parham, T.M., Jr. Properties and uses of liquid urea-triazone-based nitrogen fertilizers. Nutr. Cycl. Agroecosyst. 1991, 28, 229-232. [CrossRef]

18. Official Fertilizer Terms and Definitions, No. 42, 59, 1989. Association of American Plant Food Control Officials (AAPFCO). Available online: https://www.aapfco.org/ (accessed on 5 May 2020). 
19. Kissel, D.E.; Cabrera, M. Ammonia volatilization from urea and an experimental thiazine fertilizer. HortScience 1988, 23, 1087.

20. Kappes, C.; Carvalho, M.A.C.; Yamashita, O.M.; Silva, J.A.N. Influência do nitrogênio no desempenho produtivo do milho cultivado na segunda safra em sucessão à soja. Pesqui. Agropecu. Trop. 2009, 39, 251-259.

21. Kappes, C.; Arf, O.; Arf, M.V.; Ferreira, J.P.; Bem, E.A.D.; Portugal, J.R.; Vilela, R.G. Inoculação de sementes com bactéria diazotrófica e aplicação de nitrogênio em cobertura e foliar em milho. Semin. Ciênc. Agrár. 2013, 34, 527-538. [CrossRef]

22. Moreira, A.; Moraes, L.A.C.; Schroth, G.; Becker, F.J.; Mandarino, J.M.G. Soybean Yield and Nutritional Status Response to Nitrogen Sources and Rates of Foliar Fertilization. Agron. J. 2017, 109, 629-635. [CrossRef]

23. Liu, S.; Wang, X.; Yin, X.; Savoy, H.J.; McClure, A.; Essington, M.E. Ammonia Volatilization Loss and Corn Nitrogen Nutrition and Productivity with Efficiency Enhanced UAN and Urea under No-tillage. Sci. Rep. 2019, 9, 6610. [CrossRef]

24. De Oliveira, S.M.; Junior, C.P.; Lago, B.C.; De Almeida, R.E.M.; Trivelin, P.C.O.; Favarin, J.L. Grain yield, efficiency and the allocation of foliar N applied to soybean canopies. Sci. Agricola 2019, 76, 305-310. [CrossRef]

25. Dos Santos, H.G.; Jacomine, P.K.T.; Dos Anjos, L.H.C.; De Oliveira, V.A.; Lumbreras, J.F.; Coelho, M.R.; De Almeida, J.A.; Araujo Filho, J.C.; De Oliveira, J.B.; Cunha, T.J.F. Sistema Brasileiro de Classificação de Solos, 5th ed.; Embrapa Solos: Brasília, Brazil, 2018.

26. Soil Survey Staff. Keys to Soil Taxonomy, 12th ed.; USDA Natural Resources Conservation Service: Washington, DC, USA, 2014. Available online: https://www.nrcs.usda.gov/wps/portal/nrcs/detail/soils/survey/class/ taxonomy/?cid=nrcs142p2_053580 (accessed on 10 May 2020).

27. Peel, M.C.; Finlayson, B.L.; McMahon, T. Updated world map of koppen-geiger climate classification. Hydrol. Earth Syst. Sci. 2007, 11, 1633-1644. [CrossRef]

28. Manual de Adubação e Calagem para o Estado do Paraná, 2nd ed.; Moreira, A., Motta, A.C.V., Costa, A., Muniz, A.S., Cassol, L.C., Zanao, L.A., Jr.; Batista, M.A., Muller, M.M.L., Hager, N., Pauletti, V., Eds.; Sociedade Brasileira de Ciência do Solo-Núcleo Estadual Paraná: Curitiba, Brazil, 2019.

29. Malavolta, E.; Vitti, G.C.; De Oliveira, S.A. Avaliação do Estado Nutricional das Plantas Princípios e Aplicações; Associação Brasileira para Pesquisa da Potassa e do Fosfato: Piracicaba, Brazil, 1997.

30. Banzatto, D.A.; Kronka, S.N. Experimentação Agrícola, 4th ed.; Fundação de Apoio a Pesquisa, Ensino e Extensão: Jaboticabal, Brazil, 2008.

31. Silva, A.F.; Sediyama, T.; Borém, A. Exigências edafoclimáticas. In Soja: Do Plantio à Colheita; Sediyama, T., Silva, F., Borém, A., Eds.; UFV: Viçosa, Brazil, 2015; p. 333.

32. Farias, J.R.B.; Nepomuceno, A.L.; Neumaier, N. Ecofiosologia da Soja; Circular Técnica/Embrapa Soja: Londrina, Brazil, 2007; p. 9.

33. Fancelli, A.L. Ecofisiologia, fenologia e implicações básicas de manejo. In Milho do Plantio à Colheita; Galvão, J.C.C., Borém, A., Pimentel, M.A., Eds.; UFV: Viçosa, Brazil, 2017; p. 382.

34. Marschner, H. Mineral Nutrition of Higher Plants; Academic Press: London, UK, 2012.

35. Bondada, B.; Syvertsen, J.; Albrigo, L. Urea Nitrogen Uptake by Citrus Leaves. HortScience 2001, 36, 1061-1065. [CrossRef]

36. Dong, S.; Cheng, L.; Scagel, C.F.; Fuchigami, L.H. Nitrogen absorption, translocation and distribution from urea applied in autumn to leaves of young potted apple (Malus domestica) trees. Tree Physiol. 2002, 22, 1305-1310. [CrossRef] [PubMed]

37. Morris, D.R.; Weaver, R.W. Absorption and Translocation of Foliarly Applied 15 N by Soybeans1. Agron. J. 1907, 75, 572-574. [CrossRef]

38. Bowman, D.C.; Paul, J.L. Foliar Absorption of Urea, Ammonium, and Nitrate by Perennial Ryegrass Turf. J. Am. Soc. Hortic. Sci. 1992, 117, 75-79. [CrossRef]

39. Ling, F.; Silberbush, M. Response of maize to foliar vs. soil application of nitrogen-phosphorus-potassium fertilizers. J. Plant Nutr. 2002, 25, 2333-2342. [CrossRef]

40. Kotz-Gurgacz, T.E.; Soratto, R.P.; Guidorizzi, F.V.C. Foliar and topdressing application of nitrogen to the common bean crop. Pesquisa Agropecuária Brasileira 2018, 53, 1329-1337. [CrossRef]

41. Câmara, G.M.D.S. Fixação biológica de nitrogênio em soja. Inform. Agron. 2014, 147.

42. Serraj, R.; Sinclair, T.R.; Purcell, L.C. Symbiotic N2 fixation response to drought. J. Exp. Bot. 1999, 50, $143-155$. [CrossRef] 
43. King, C.A.; Purcell, L.C. Soybean Nodule Size and Relationship to Nitrogen Fixation Response to Water Deficit. Crop. Sci. 2001, 41, 1099-1107. [CrossRef]

44. Streeter, J.G. Effects of drought on nitrogen fixation in soybean root nodules. Plant Cell Environ. 2003, 26, 1199-1204. [CrossRef]

45. Souza, E.; Soratto, R. Efeito de Fontes e Doses de Nitrogênio em Cobertura, no Milho Safrinha, em Plantio Direto. Rev. Bras. Milho Sorgo 2006, 5, 395-405. [CrossRef]

46. Cruz, S.C.S.; Pereira, F.R.D.S.; Santos, J.R.; De Albuquerque, A.W.; Pereira, R.G. Nitrogen fertilization for corn cultivated under a no-tillage system in the state of alagoas. Braz. Rev. Bras. Eng. Agric. Ambient. 2008, 12, 62-68. [CrossRef]

47. Borrás, L.; Otegui, M.E. Maize Kernel Weight Response to Postflowering Source-Sink Ratio. Crop. Sci. 2001, 41, 1816-1822. [CrossRef]

48. Shioga, P.S.; Oliveira, E.; Gerage, A. Densidade de Plantas e Adubação Nitrogenada em Milho Cultivado na Safrinha. Rev. Bras. Milho Sorgo 2004, 3, 381-390. [CrossRef]

(C) 2020 by the authors. Licensee MDPI, Basel, Switzerland. This article is an open access article distributed under the terms and conditions of the Creative Commons Attribution (CC BY) license (http://creativecommons.org/licenses/by/4.0/). 